\title{
Cephalofacial Morphological Characteristics of Albanian Kosova Population
}

\author{
Características Morfológicas Cefalofaciales de la Población Albanesa de Kosovo
}

\author{
Agron Rexhepi \& Vjollca Meka
}

REXHEPI, A. \& MEKA, V. Cephalofacial morphological characteristics of Albanian Kosova population. Int. J. Morphol., 26(4):935940, 2008.

SUMMARY: Although the human race must be regarded as a unit intellectually and physically, from the anthropologists' viewpoint the particular set of bones most often measured for purposes of racial classification are those of the head. The aim of the present work was to determine some relevant cephalofacial parameters, particularly in relation to sex and to study the distribution of basic head and face types of a Kosova Albanian population. The study sample comprised 754 subjects of both sex (561 male and 193 female) aged 18 to 35 from Kosova. Five basic cephalofacial variables were measured to obtain the head and face indexes. Statistically significant differences between two treated groups, according to sex, were found almost in all measured cephalofacial variables. Such proportional differences did not influence only the Total Facial Index. According to the horizontal cephalic index the head of the treated subjects $(51.9 \%$ males, $46.1 \%$ females) mainly belongs to brachiocephalic type; According to the vertical cephalic index $48.4 \%$ of the treated male entities and $40.4 \%$ of the female entities belongs to the type with low hypsicephalic head. According to the transverse cephalic index both treated entities mainly (male $66.8 \%$ and female $75.1 \%$ ) belongs to the group with tapeinocephalic type of the head. According to the total facial index the treated male entities are mainly distributed in two types of the face: leptoprosop type (31.2\%) and hyperleptoprosop type (31.6\%), whereas the female entities are mostly (48.7\%) concentrated in hyperleptoprosop facial type.

KEY WORDS: Anthropological; Cephalofacial; Facial index; Cephalic index.

\section{INTRODUCTION}

Although the human race must be regarded as a unit intellectually and physically, from the anthropologists' viewpoint the particular set of bones most often measured for purposes of ethno-anthropological researches are those of the head. The information collected from measurements of the cephalofacial, respectively craniofacial variables, enables a chronological study of the anthropological status of the nations and helps comparison of the anthropological features of the today's nations and previous nations too (Coon, 1939; Dhima, 1985; Ylli, 1975).

In cephalometric studies among currently methods (photogrametry, ultrasound, computed tomographic, scanning magnetic imaging, optical surface scanning, cephalometry) cephalometry continues to be the most versatile technique in the investigation of the craniofacial skeleton because of its validity and practicality.

The type of the head and face depend on many factors, such as racial and ethnical affiliation, genetic influence, traditions, nutrition, environment, and climate. The cephalofacial indexes are different for different people. People with a horizontal cephalic index of less than 76 have long, narrow head, and belong to dolichocephalic type of the head. If the cephalic index is more than 80.9, the head appears to be short and broad; those people belong to brachyocephalic type of the head. People with cephalic index between 76 and 80.9 belong to mesocephalic type of the head.

The head of the Dinaric type of humans (Illyrians) is characterized with a high breadth of the head, a medium length of the neurocranium (often back part is somewhat flattened), the vertical height of the cranium is high, and the face is long and wide. The horizontal cephalic index indicates that their head belongs to brachycephalic type (Coon, 1939; Dhima; Günter, 1927; Mcculloch, 2008; Ylli).

Because the population in the Albanian territories belongs to the Dinaric type of the humans, many 
anthropologists are interested on morphological type of the Albanians. The first anthropological researches on Albanians were done by Weissbach, on 1868 and Glück L. on 1895-1896 (Glück, 1987).

The aim of the present work was to determine some relevant cephalofacial parameters, particularly in relation to sex, and to study the distribution of basic head and face types of a Kosova Albanian population.

\section{MATERIAL AND METHOD}

This research is a part of the project: "Morphological characteristics of Kosova Albanian population" realized by the Institute of Sports Anthropology in Prishtina, Kosova.

In this study, five cephalofacial measurements were done in 754 entities of the Kosova Albanian population (561 male and 193 female), 18 - 35 years of age, chosen randomly, always respecting the rule that their psycho-physic, dental and soft tissue condition were in normal. So, all pathological cases and cases with body abnormality (deformity) were eliminated from further study and measurements.

Since Prishtina represents a mix of Kosova's Albanian population, all the participants were chosen to be inhabitants of the Prishtina. The measurements were done in the Institute of Sport Anthropology and in the Sport Medicine Centre and Rehabilitation in Prishtina, period 1997-2002, the measurer was Agron Rexhepi.

Following the definitions of Martin \& Saller (1957) the measurements were taken by an anthropological cephalometer GMP, with measurement interval of $300 \mathrm{~mm}$ and accuracy of $1 \mathrm{~mm}$, and a sliding rule modified for cephalometric and gnathometric measurements. The following variables were measured:

GJATKOK - Maximum head length (glabela-opistocranion, g-op) was measured by spreading caliper. The anterior caliper tip was resting on glabella, whereas the posterior tip slid inferiorly along medial line of occipital until maximum length was reached.

GJERKOK - Maximum head breadth (eurion-eurion, eueu) was measured by spreading caliper, sliding both tips of caliper down lateral sides of parietal bones, forward and back until maximum width was reached.

LARTKOK - Head height (vertex-porion, v-po) was measured on the right and left sides of the head using a double sliding caliper and a level.

LARMOFY - Morphological height of the face (nasiongnation, n-gn) was meausured by sliding caliper. The fixed tip of caliper was placed at the subject's gnathion and the moveable end on nasion.

GJERFYT - Maximum facial breadth (bizygomatic, zy-zy) was measured by spreading caliper. First by palpation were located the most lateral point of the zygomatic arch, with the tips of index fingers were placed the caliper tips on the arches with enough pressure to feel the bone, than were moved the caliper back and forth, up and down until scale shown maximum reading.

On the basis of basic measurement data (above variables) were calculated:

HCI - Horizontal cephalic index, respectively the proportion of the maximum breadth of the head in relation to the length of the head was calculated according to the formulae:

HCI = (eu-eu / g-op) x 100.

VCI - Vertical cephalic index, respectively the ratio of the maximum height of the head to its maximum length was calculated according to the formulae:

$\mathrm{VCI}=(\mathrm{v}-\mathrm{po} / \mathrm{g}$-op $) \times 100$.

TCI - Transverse cephalic index, respectively the proportion of the maximum head height to its maximum breadth was calculated according to the formulae:

TCI $=(\mathrm{v}-$ po $/$ eu-eu $) \times 100$.

TFI - Total facial index, respectively the relation of the morphological height of the face to its maximum breadth (between zygomatic prominences) was calculated according to the formulae:

$$
\mathrm{TFI}=(\mathrm{n}-\mathrm{gn} / \mathrm{zy}-\mathrm{zy}) \mathrm{x} 100 .
$$

The following values were applied for distribution of particular craniofacial types (According to Martin-Saller scale):

HCI - Horizontal cephalic index.

VCI - Vertical cephalic index.

TCI - Transverse cephalic index

TFI - Total facial index

The obtained data were analyzed in terms of basic statistical parameters. While the categorization of the treated entities by their cephalofacial features (indexes) were done based on the distribution of their index-values according to respective scale. 


\section{RESULTS AND DISCUSSION}

The findings of basic statistic parameters (X, Min. and Max. values, and SD) for the measured variables in treated subjects (male and female entities), and significance of their differences according to sex, are shown in Table I. The differences between the two groups were submitted to T-test for independent samples (statistical package SPSS 15 for Windows).

Recorded mean values for the measured variables, which determine the cephalofacial morphological features, in treated female entities are lower in relation to the mean values of these variables in male entities. Statistically significant differences between two treated groups (Table I), according to sex, were found almost in all measured cephalofacial variables. Such proportional differences did not influence only the total facial index.

According to the mean values of the measured head morphological variables of the male tested entities (Table I), our results of the head length (188.79) and the head width (157.71) are similar with the results of Gavrilovic ${ }^{2}(1969)$ (188.61; 156.7) and Coon $(186.18 ; 157.78)$, whereas our result of the head height (121.52) is similar with the results of Pittard (121.4) and Tildesley (121.40) (Gavrilovic ‘ ; Coon, 1950; Pittard, 1916).
In Tables II, III, IV and V are presented the categorization and distribution of the values for the cephalofacial indexes of the treated entities (HCI, VCI, TCI, TFI), according to respective scale.

The categorization of the head with regard to the horizontal cephalic index (Table II) shows that the majority of the treated population (male entities $51,9 \%$ and female entities $46.1 \%$ ) belonged to the group with short head (brachiocephalic type).

According to the Table I, the horizontal cephalic index counted in treated entities shows that the treated male entities with mean value of the $\mathrm{HCI}=83.59$ (variations 61.7-100.5), as well and the females with $\mathrm{HCI}=84.79$ (variation 73.794.1) belonged to the group of people with brachiocephalic type of the head. Similar results of the HCI were found in studies of Pittard, Haberlandt \& Lebzelter (1919), Glück, Drontc`ilov (1921), Coon (1950), Gavrilovic``, Ylli, Dhima, Behluli (1987).

According to the percentage (\%) of the male tested entities which were characterized with a long head (Dolichocephalic type), our result (2.3\%) is closer with result (2.7\%) of the author Drontc $`$ ilov. According to Haberlandt

Table I. Descriptive statistics and T-test.

\begin{tabular}{lrrrrrrrrrr}
\hline & \multicolumn{9}{c}{ Male } & \multicolumn{7}{c}{ Female } \\
\hline Variables: & Min & Max & $\mathbf{X}$ & SD & Min & Max & $\mathbf{X}$ & SD & t & p \\
GJATKOK & 168.00 & 209.00 & 188.79 & 6.31 & 164.00 & 200.00 & 180.14 & 6.53 & 16.3 & .00 \\
GJERKOK & 116.00 & 191.00 & 157.71 & 6.46 & 138.00 & 168.00 & 152.61 & 5.72 & 9.7 & .00 \\
LARTKOK & 104.00 & 143.00 & 121.52 & 6.97 & 96.00 & 134.00 & 114.67 & 6.92 & 11.8 & .00 \\
LARMOFY & 105.00 & 144.00 & 122.44 & 6.45 & 97.00 & 132.00 & 112.83 & 5.5 & 18.5 & .00 \\
GJERFYT & 109.00 & 155.00 & 135.87 & 8.12 & 105.00 & 142.00 & 125.36 & 7.4 & 16.0 & .00 \\
HCI & 61.70 & 100.53 & 83.59 & 3.72 & 73.68 & 94.12 & 84.79 & 3.64 & -3.9 & .00 \\
VCI & 52.74 & 76.00 & 64.41 & 3.80 & 53.85 & 76.57 & 63.72 & 4.26 & 2.1 & .04 \\
TCI & 63.64 & 93.97 & 77.14 & 4.85 & 63.13 & 92.86 & 75.22 & 5.07 & 4.7 & .00 \\
TFI & 74.31 & 115.60 & 90.38 & 6.45 & 77.60 & 109.01 & 90.27 & 6.32 & .21 & .83 \\
\hline
\end{tabular}

Table II. Horizontal cephalic index (Martin-Saller scale).

\begin{tabular}{llrrrrr}
\hline & \multicolumn{3}{c}{ Male } & \multicolumn{3}{c}{ Female } \\
\hline Dolichocephalic & $71.0-75.9$ & 13 & $2.3 \%$ & $72.0-76.9$ & 1 & $0.5 \%$ \\
Mesocephalic & $76.0-80.9$ & 110 & $19.6 \%$ & $77.0-81.9$ & 38 & $19.7 \%$ \\
Brachycephalic & $81.0-85.9$ & 291 & $51.9 \%$ & $82.0-86.4$ & 89 & $46.1 \%$ \\
Hyperbrachycephalic & $86.0-90.9$ & 140 & $25.0 \%$ & $86.5-91.9$ & 60 & $31.1 \%$ \\
Ultrabrachycephallic & $91.0-\mathrm{x}$ & 7 & $1.2 \%$ & $92.0-\mathrm{x}$ & 5 & $2.6 \%$ \\
\hline
\end{tabular}


REXHEPI, A. \& MEKA, V. Cephalofacial morphological characteristics of Albanian Kosova population. Int. J. Morphol., 26(4):935-940, 2008.

Table III. Vertical cephalic index (Martin-Saller scale).

\begin{tabular}{llrrrr}
\hline & & \multicolumn{1}{c}{ Male } & \multicolumn{2}{c}{ Female } \\
\hline Chamaecephalic & $\mathrm{x}-57.9$ & 21 & $3.7 \%$ & 12 & $6.2 \%$ \\
Orthocephalic & $58.0-62.9$ & 176 & $31.4 \%$ & 72 & $37.3 \%$ \\
Low Hypsicephalic & $63.0-67.9$ & 271 & $48.3 \%$ & 78 & $40.4 \%$ \\
Moderate Hypsicephalic & $68-72.9$ & 84 & $15.0 \%$ & 27 & $14.0 \%$ \\
High Hypsicephalic & $73-\mathrm{x}$ & 9 & $1.6 \%$ & 4 & $2.1 \%$ \\
\hline
\end{tabular}

Table IV. Transverse cephalic index (Martin-Saller scale).

\begin{tabular}{lrrrrc}
\hline & & \multicolumn{2}{c}{ Male } & \multicolumn{2}{c}{ Female } \\
\hline Tapeinocephalic & $\mathrm{X}-78.9$ & 375 & $66.8 \%$ & 145 & $75.1 \%$ \\
Metriocephalic & $79-84.9$ & 148 & $26.4 \%$ & 42 & $21.8 \%$ \\
Acrocephalic & $85-\mathrm{X}$ & 38 & $6.8 \%$ & 6 & $3.1 \%$ \\
\hline
\end{tabular}

Table V. Total facial index (Martin-Saller scale).

\begin{tabular}{lrrrrrr}
\hline & \multicolumn{5}{c}{ Male } & \multicolumn{3}{c}{ Female } \\
\hline Hypereuriprosop & $\mathrm{x}-78.9$ & 8 & $1.4 \%$ & $\mathrm{x}-76.9$ & 0 & $0.0 \%$ \\
Euryprosop & $79.0-83.9$ & 77 & $13.7 \%$ & $77.0-80.9$ & 9 & $4.7 \%$ \\
Mesoprosop & $84.0-87.9$ & 124 & $22.1 \%$ & $81.0-84.9$ & 32 & $16.6 \%$ \\
Leptoprosop & $88.0-92.9$ & 175 & $31.2 \%$ & $85.0-89.9$ & 58 & $30.0 \%$ \\
Hyperleptoprosop & $93.0-\mathrm{x}$ & 177 & $31.6 \%$ & $90.0-\mathrm{x}$ & 94 & $48.7 \%$ \\
\hline
\end{tabular}

Table VI. Horizontal cephalic index of the balkan people - according to Pittard.

\begin{tabular}{lccc}
\hline & Dolichocephalic & Mesocephalic & Brachyecephalic \\
\hline Bulgarian & $34.00 \%$ & $22.00 \%$ & $24.00 \%$ \\
Greek & $33.79 \%$ & $17.24 \%$ & $48.97 \%$ \\
Serb & $39.20 \%$ & $30.70 \%$ & $29.80 \%$ \\
Albanian & $8.90 \%$ & $11.60 \%$ & $79.50 \%$ \\
\hline
\end{tabular}

\& Lebzelter $5 \%$ of the Albanians are characterized with dolichocephalic type of the head, whereas according to Pittard 9\%.

The categorization of the head with regard to the vertical cephalic index (Table III) shows that the majority of the treated population (male $48.3 \%$ and female entities $40.4 \%$ ) belonged to the group with low hypsicephalic type of the head.

Table I shows that the treated male entities with mean value of the vertical cephalic index $\mathrm{VCI}=64.41$ (variations 52.74-76), and the females with $\mathrm{VCI}=63.72$ (variation 53.8576.57) belonged to the group of people with low hypsicephalic type of the head. Distribution of the treated male and female entities by their transverse cephalic index values was similar (Table IV). Both treated entities were mainly concentrated in the group with tapeinocephalic type of the head $($ male $=66.8 \%$, female $=75.1 \%)$.

Table I shows mean values with variation for both treated entities regarding to the transverse cephalic index. Based in data of the Table I, the males with mean value of the TCI=77.14 (variation 63.64-93.97) and the females with TCI=75.22 (variation 63.13-92.86) were characterized with tapeinocephalic type of the head.

Distribution of the treated entities based on the total facial index values is shown in Table V. According to this table the treated male entities are mainly distributed in two morphological types of the face: leptoprosop (31.2\%) and hyperleptoprosop type $(31.6 \%)$. The female entities are mostly $(48.7 \%)$ concentrated in hyperleptoprosop facial type. 
Based on the mean value of the total facial index (Table I) the treated male entities with TFI $=90.38$ (variation 74.31-115.6) belonged to the leptoprosop facial type, and the females with TFI=90.27 (variation 77.6-109.01) belonged to hyperleptoprosop facial type.

Table VI shows the comparison of some Balkan populations according to their horizontal cephalic index.

According to the table VI, Albanians have higher values of the $\mathrm{HCI}$ with regards to the other Balkan people. A lot of anthropologists' investigations say that approximately $80 \%$ of the Albanian people (in our research $76.9 \%$, Table II) have a brachycephalic and hyperbrachycephalic type of the head (Behluli; Dhima; Gavrilovic²; Glück; Mcculoch; Ylli). After the Albanians, aligning of the other populations according to the size of the horizontal cephalic index looks like this: Tartars, Romans, Turks, Greeks, Serbs, Bulgarians, etc. (Ylli).

Based on analysis of the results and discussion of this research, the following conclusions can be made: According to sex, the two treated groups show statistically significant differences in mean values of all measured cephalofacial variables, excepting the total facial index.

Statistically significant differences between treated entities (males and females), with regard to morphological head features, expressed sexual dimorphism.

According to the indexes of the head in entities of both sexes predominated, brachyocephalic, Low hypsicephalic and tapeinocephalic type of the head.

According to the total facial index, male entities are characterized with leptoprosop and hyperleptoprosop type of the face, while females with hyperleptoprosop type.

The morphologic types of the current population could not be easy separated, because among the different types interfere types with intermediate features (Behluli; Coon; Dhima; Ylli). But, in general the morphological features of the head from this research, match with the results of the other authors, who found similarities between the morphologic features of the dinaric type (Illyrians) and Albanian population (Behluli; Coon, 1950, 1939; Drontc `ilov; Dhima; Glück; Günter; Haberland \& Lebzelter; Mcculoch; Tidlesley; Ylli).

REXHEPI, A. \& MEKA, V. Características morfológicas cefalofaciales de la población albanesa de Kosovo. Int. J. Morphol., 26(4):935940, 2008.

RESUMEN: A pesar que la raza humana debe considerarse como una unidad intelectual y físicamente hablando, desde el punto de vista de los antropólogos, la particular serie de huesos que con mayor frecuencia son medidos para efectos de clasificación racial, son los de la cabeza. El objetivo del presente trabajo fue determinar algunos parámetros cefalofaciales pertinentes, en particular los relacionados con el sexo, para estudiar la distribución básica del tipo de cabeza y cara en una población albanesa de Kosovo. La muestra del estudio fue de 754 sujetos, de ambos sexos (561 varones y 193 mujeres), entre 18 y 35 años, de Kosovo. Cinco variables cefalofaciales básicas fueron medidas para obtener índices de la cabeza y cara. Diferencias estadísticamente significativas entre los dos grupos estudiados, de acuerdo al sexo, se encontraron casi en todas las variables cefalofaciales medidas. Estas diferencias proporcionales no sólo influyen en el índice facial total. Según el índice cefálico horizontal de la cabeza de los sujetos estudiados (51,9\% hombres, 46,1\% mujeres), principalmente pertenecen al tipo braquiocefálico. De acuerdo con el índice cefálico vertical el 48,4\% de los varones estudiados y el 40,4\% de las mujeres pertenecen al tipo de cabeza con hipsicefalia baja. Según el índice cefálico transversal ambos grupos de sujetos estudiados $(66,8 \%$ varones y mujeres $75,1 \%)$ presentan principalmente cabeza tapeinocefálica. Según el índice facial total de los varones estudiados se distribuyen principalmente en dos tipos de cara: tipo leptoprosopo $(31,2 \%)$ y tipo hiperleptoprosopo (31,6\%), mientras que la mayoría de las mujeres $(48,7 \%)$ se concentraron en el tipo facial hiperleptoprosopo.

PALABRAS CLAVE: Antropología; Céfalofacial; Índice facial; Índice cefálico.

\section{REFERENCES}

Behluli, I. Biometrijska analiza morfolos ${ }^{`} k i h$ i fiziolos ${ }^{\mathrm{k}} \mathrm{kih}$ svojstava u odraslih osoba s obzirom na funkciju respiratornog sistema. $\mathrm{PhD}$ dissertation. University of Prishtina, Kosova, 1987.

Coon, C. S. The races of Europe. $2^{\text {nd }}$ Edition. Macmillan, New York, 1939. p. 293.
Coon, C. S. The mountains of Giants. A Racial and Cultural Study of the North Albanian Mountain Ghegs. Cambridge, Massachusetts, 1950. p. 105.

Dhima, D. H. A. Gjurmime antropologjike për shqiptarët. Tirana, 1985. pp28-9, 106-12, 126-8. 
Drontc`ilov, K. Prinos kàm antropologijata na Albancite. Periodichesko spisanie na Balgarskoto Knizhovno Druzhestvo, 21:111-37, 1921.

Gavrilovic $` Z^{`}$. Antropolos`ki podaci o osobama iz Dec`ana. Glasnik ADJ, 6:13-23, 1969.

Glück, L. Zur physischen anthropologie der Albanesen. Wissenschaften und Mitteilungen aus Bosnien und der Hercegovina, 5:365:402, 1897.

Günter, H. F. K. The racial elements of European history. Methuen and Company, London, 1927.

Haberlandt, A. \& Lebzelter, V. Zur physischen Antropologie der Albaner. Archiv für Anthropologie, 45:123-42, 1919.

Martin, R. \& Saller, K. Lehrbuch der anthropologie. Fischer, Stuttgart, 1957.

Mcculloch, R. The nordish race. Available from: http:// www.racialcompact.com/nordishrace.html. 2007. Accessed 15.03.2008.

Pittard, E. Les peuples des Balkans. First edition. Attinger frères, Paris, 1916. pp.84-5.

Tildesley, M. L. The Albanians of the north and south. Biometrika, 25:21-51, 1933.

Ylli, A. Disa t? dh?na kraniometrike. Tirana, 1975. p.6497.
Correspondence to:

Agron Rexhepi

Str. " Sali Butka" Nr. 31/D, 10020

Pristina,

KOSOVA

Phone: +37744110855

Email: agronmrexhepi@gmail.com

Received: 17-06-2008

Accepted: 22-09-2008 